\title{
Hjertesykdom i familien?
}

\section{Systematisk kartlegging av kardiovaskulær sykdom i familien kan gjøre det lettere å avgjøre hvilke pasienter som trenger forebyggende behandling}

I en britisk studie fra allmennpraksis ble 748 pasienter uten tidligere påviste risikofaktorer for kardiovaskulær sykdom vurdert på vanlig måte (1). Etter en paret clusterrando- misering ble om lag halvparten av dem også bedt om å fylle ut et spørreskjema om forekomst av hjerte- og karsykdom i familien.

Andelen pasienter som ble klassifisert

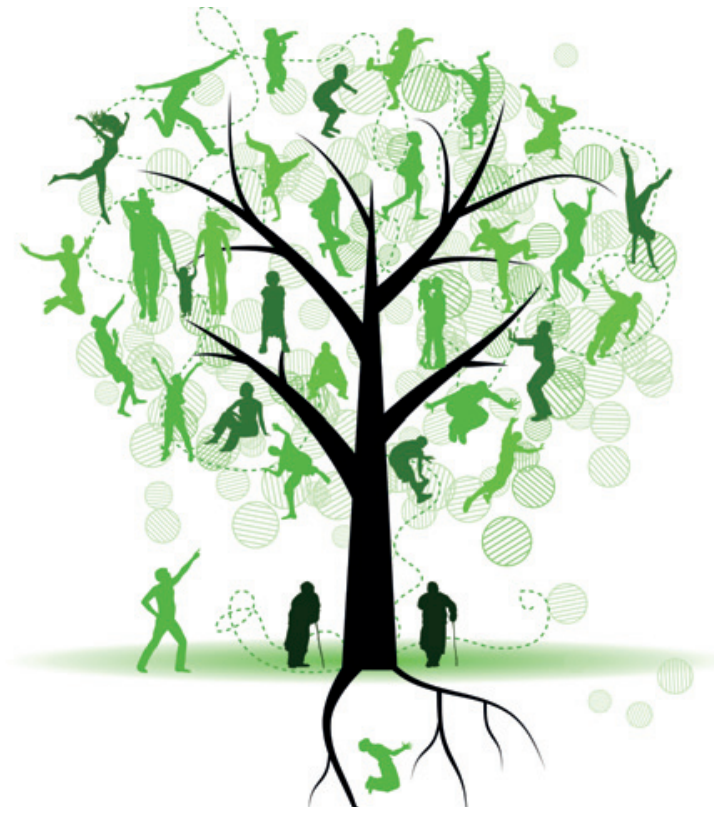

med høy risiko for kardiovaskulær sykdom, steg med 4,8 prosentpoeng i intervensjonsgruppen mot 0,3 prosentpoeng i kontrollgruppen $(\mathrm{p}=0,007)$. Angstskår var lik i begge grupper.

- Dette er en god studie, som viser hvor viktig det er å kartlegge forekomst av kardiovaskulær sykdom i slekten når samlet risiko skal vurderes og det planlegges forebyggende tiltak, for eksempel behandling med blodtrykkssenkende legemidler, sier professor Åsmund Reikvam ved Farmakologisk institutt, Institutt for klinisk medisin ved Universitetet i Oslo.

- I retningslinjer om forebyggende medikamentell behandling mot hjerte- og karsykdom er det vanlig at beregning av absolutt risiko for koronarsykdom eller hjerneslag inngår. Slike beregninger omfatter ofte ikke familiær forekomst av hjerte- og karsykdom. Det er likevel vanlig å ta hensyn til familiær belastning i den skjønnsmessige vurderingen som må gjøres i tillegg til risikoberegningen, sier Reikvam.

\section{Petter Gjersvik \\ petjense@online.no \\ Tidsskriftet}

\section{Litteratur}

1. Qureshi N, Armstrong S, Dhiman P et al. Effect of adding systematic family history enquiry to cardiovascular disease risk assessment in primary care a matched-pair, cluster randomized trial. Ann Intern Med 2012; 156: 253-62.

\section{Lovende resultater med brakyterapi mot prostatakreft}

Appendiks på www.tidsskriftet.no/raabeappendiks

\section{Ved høydoserate brakyterapi \\ implanteres strålekilder med kort rekkevidde direkte inn i prostata. \\ Kombinert med hormoner og eks- tern strålebehandling oppnås god tumorkontroll og gode langtids- resultater hos pasienter med aggressiv sykdomsprofil.}

Prostatakreft er den hyppigste kreftsykdom i Norge, og dødeligheten er den høyeste i Europa. Ekstern strålebehandling og hormonbehandling tilbys oftest pasienter med høy risiko for spredning. Eskalering av stråledosen øker lokal tumorkontroll, sykdomsfritt intervall og kurasjonsraten. Imidlertid øker også risikoen for langtidsbivirkninger og forringet livskvalitet. Viktigste begrensende faktor for totaldose er toleransen til bløtvevsstrukturer omkring prostata.
Ved høydoserate brakyterapi (høy stråledose per tidsenhet) implanteres en trådformet radioaktiv kilde (192 iridium) med kort rekkevidde inn i prostatakjertelen gjennom hule stålnåler. Kombinasjonen høydoserate brakyterapi og ekstern strålebehandling øker dosebidraget $\mathrm{i}$ prostata med ca. $25 \%$ uten tilsvarende risiko for økt toksisitet i naboorganer (1).

Fra 2004 har vi behandlet 530 pasienter med høydoserate brakyterapi. Fra denne gruppen har vi selektert de 275 første pasientene, derav $93 \%$ i høyrisikogruppen, med en median oppfølgingstid på minst 3,5 år som alle fikk hormonbehandling, høydoserate brakyterapi og ekstern strålebehandling (2). Vi har beskrevet svært gode langtidsresultater og omtalt bivirkninger og behandlingsrelaterte komplikasjoner (appendiks). 12 pasienter fikk residiv. Sykdomsfri overlevelse var 95,6\%, cancerspesifikk overlevelse $99,3 \%$ og totaloverlevelsen $96,3 \%$ - et resultat som er blant de beste i verden.
Bivirkningene fra rectum og urinveiene etter høydoserate brakyterapi er moderate og avtakende over tid. Denne terapien gis i Norge bare ved Oslo universitetssykehus, Radiumhospitalet, og er nå standard prosedyre ved lokalisert og lokalavansert prostatakreft uten metastaser på diagnosetidspunktet.

\footnotetext{
Nils K. Raabe

nkr@ous-hf.no

Gunnar Tafjord

Wolfgang Lilleby

Oslo universitetssykehus, Radiumhospitalet

Litteratur

1. Raabe NK, Lilleby W, Tafjord G et al. Høydoserate brakyterapi ved prostatakreft i Norge. Tidsskr Nor Legeforen 2008; 128: 1275-8.

2. Lilleby W, Tafjord G, Raabe NK. Implementation of high-dose-rate brachytherapy and androgen deprivation in patients with prostate cancer. Int J Radiat Oncol Biol Phys 2011; e-publisert 2.12.2011.
} 